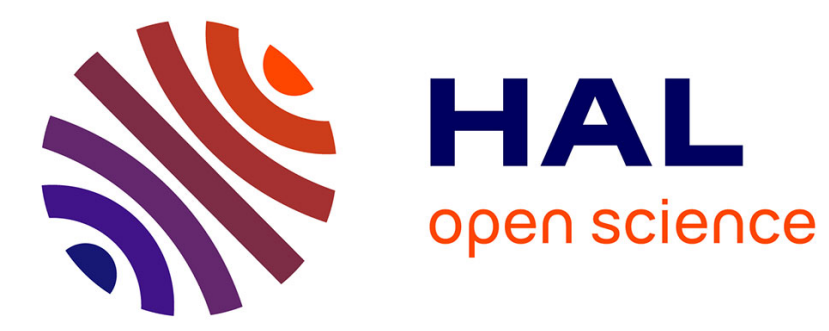

\title{
Effect of non-magnetic and magnetic trivalent ion substitutions on BaM-ferrite properties synthesized by hydrothermal method
}

\author{
Tayssir Ben Ghzaiel, Wadia Dhaoui, Alexandre Pasko, Frédéric Mazaleyrat
}

\section{- To cite this version:}

Tayssir Ben Ghzaiel, Wadia Dhaoui, Alexandre Pasko, Frédéric Mazaleyrat. Effect of non-magnetic and magnetic trivalent ion substitutions on BaM-ferrite properties synthesized by hydrothermal method. Journal of Alloys and Compounds, 2016, 671, 10.1016/j.jallcom.2016.02.071 . hal-01316630

\author{
HAL Id: hal-01316630 \\ https://hal.science/hal-01316630
}

Submitted on 17 May 2016

HAL is a multi-disciplinary open access archive for the deposit and dissemination of scientific research documents, whether they are published or not. The documents may come from teaching and research institutions in France or abroad, or from public or private research centers.
L'archive ouverte pluridisciplinaire HAL, est destinée au dépôt et à la diffusion de documents scientifiques de niveau recherche, publiés ou non, émanant des établissements d'enseignement et de recherche français ou étrangers, des laboratoires publics ou privés. 


\section{Effect of Non-Magnetic and Magnetic Trivalent Ion}

Substitutions on BaM-Ferrite Properties Synthesized

\section{by Hydrothermal Method}

Tayssir BEN GHZAIEL ${ }^{\mathrm{a}, \mathrm{b}, *}$, Wadia DHAOUI ${ }^{\mathrm{a}}$, Alexandre PASKO $^{\mathrm{b}}$, Frédéric MAZALEYRAT $^{\mathrm{b}}$

${ }^{\text {a } U n i v e r s i t e ́ ~ d e ~ T u n i s ~ E l ~ M a n a r ~ F a c u l t e ́ ~ d e s ~ S c i e n c e s ~ d e ~ T u n i s, ~ U R 11 E S 18 ~ U n i t e ́ ~ d e ~ R e c h e r c h e ~ d e ~ C h i m i e ~}$ Minérale Appliquée, 2092, Tunis, Tunisie

${ }^{\text {b }}$ SATIE, ENS Cachan, CNRS, Université Paris-Saclay, 61 av du Président Wilson, F-94230 Cachan, France

*Corresponding author. Tel. +33754049118

E-mail address: tayssir.ben-ghzaiel@satie.ens-cachan.fr 
GRAPHICAL ABSTRACT

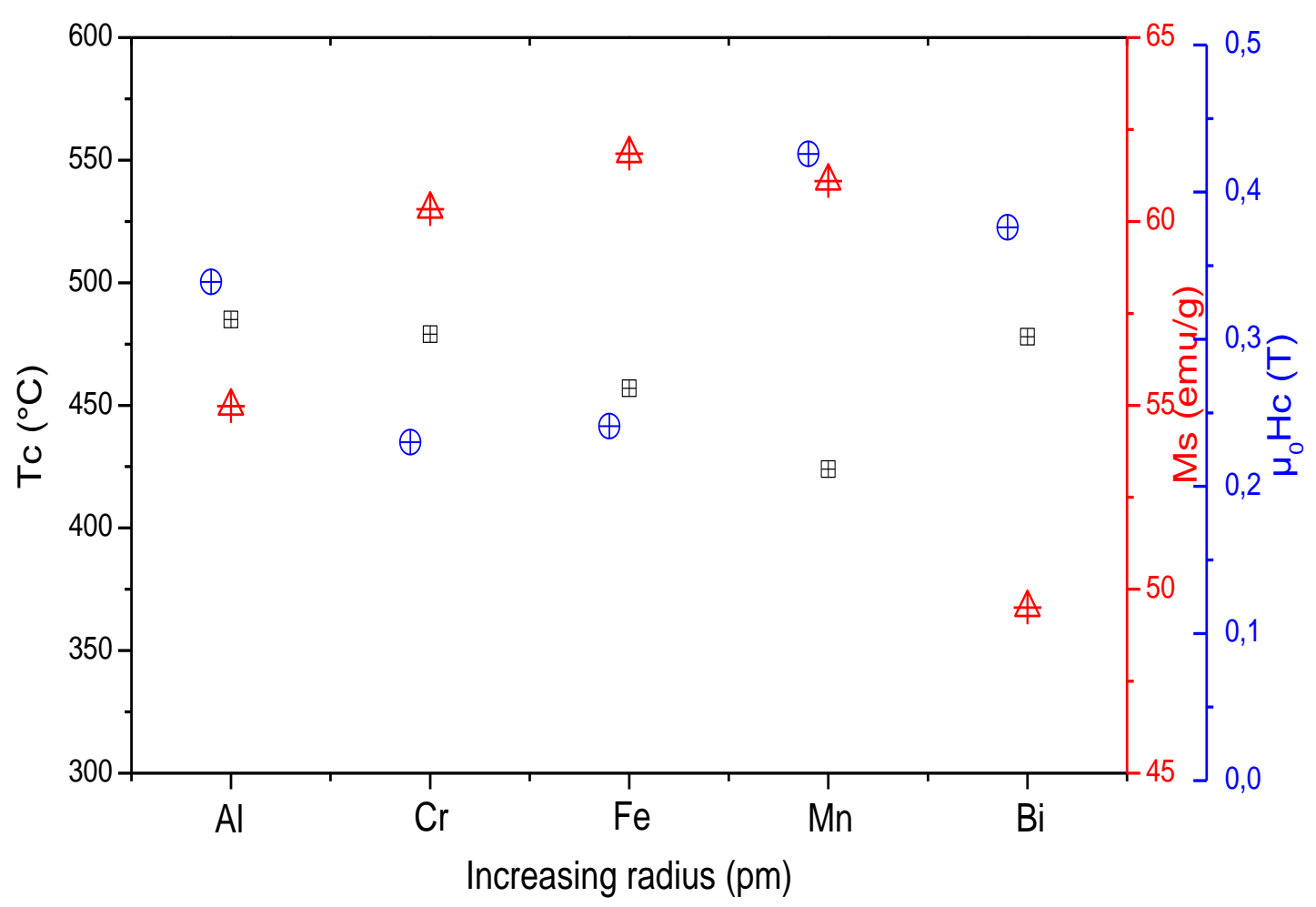




\section{Abstract}

Two spices trivalent transition metal ions, nonmagnetic $\mathrm{Al}^{3+}, \mathrm{Bi}^{3+}$ and magnetic $\mathrm{Cr}^{3+}$, $\mathrm{Mn}^{3+}$ substituted barium hexaferrite powders are synthesised via dynamic hydrothermal method then calcinated at different temperatures. Powder XRD patterns analysis and Rietveld refinement indicate magnetoplumbite-type crystalline phase. The crystallite size calculated using Scherer's formula varies from 153 to $248 \mathrm{~nm}$ as it is affected by the ionic radius of trivalent metal ions and calcination temperatures. The morphological features show agglomerations of spherical-shaped particles with an average size of $400 \pm 50 \mathrm{~nm}$ for $\mathrm{BaBiFe}_{11} \mathrm{O}_{19}$ and hexagonal-shaped particles $1-2 \mu \mathrm{m}$ for the other substitutions. Magnetic studies show a ferromagnetic behaviour for all samples. The nonmagnetic $\mathrm{Al}^{3+}, \mathrm{Bi}^{3+}$ substituted materials have lower saturation magnetization $\mathrm{Ms}$ and remanence $\mathrm{Mr}$ than the magnetic substitutions $\mathrm{Cr}^{3+}, \mathrm{Mn}^{3+}$. These results reveal that Ms and Mr are related to the magnetic moment of each metallic ion and its distribution in the lattice. For magnetic substitution, Ms of manganese substitution $(61.10 \mathrm{emu} / \mathrm{g})$ is found higher than that of chromium $(60.33 \mathrm{emu} / \mathrm{g})$ since $\mathrm{Mn}^{3+}$ has a magnetic moment of $5 \mu_{\mathrm{B}}$ greater than $\mathrm{Cr}^{3+}$ with $3 \mu_{\mathrm{B}}$. Coercivity $\mathrm{Hc}$ and maximum energy product $(\mathrm{BH})_{\max }$ determined from $\mathrm{M}-\mathrm{H}$ loops exhibit an increasing trend with calcination temperature as they are related to the crystallite size. $\mathrm{Hc}$ and $(\mathrm{BH})_{\max }$ of $\mathrm{BaMnFe}_{11} \mathrm{O}_{19}$ are found maximum $0.426 \mathrm{~T}$ and $7.47 \mathrm{~kJ} . \mathrm{m}^{-3}$, respectively.

Keywords: Magnetically ordered materials; Crystal structure; Magnetisation; Magnetic measurement; Scanning electron microscopy, SEM; X-ray diffraction. 


\section{Introduction}

Ferrimagnetic oxides have received considerable attention in the few last decades owing to their remarkable magnetic characteristics such as high Curie temperature, large permeability, high saturation magnetization and magnetocristalline anisotropy [1]. The diverse magneto-electric properties displayed by these materials have given rise to a great variety of compounds for technological and industrial applications [2].

Ferrites are ferrimagnetic oxides divided into three families: spinel, garnet and hexagonal. Among the family of hexagonal ferrite, barium hexaferrite $\mathrm{BaFe}_{12} \mathrm{O}_{19}(\mathrm{BaM})$ with magnetoplumbite structure $(\mathrm{P} 63 / \mathrm{mmc})$ is well known as hard magnetic material with strong magnetocristalline anisotropy along c-axis, high Curie temperature $(\mathrm{Tc}=$ $472{ }^{\circ} \mathrm{C}$ ), relatively high magnetization saturation, high electrical resistivity, chemical stability and resistance to corrosion [3]. These properties arise from exchanges between the oxygen and metallic ions occupying particular positions in its hexagonal crystalline structure.

Several investigations on the substituted barium ferrite have been carried out to further improve its magnetic and electrical properties. A proper cation substitution on iron ions, in tetrahedral and octahedral site of BaM unit cell, by trivalent magnetic or nonmagnetic metal ions or with appropriate arrangement of bivalent and tetravalent cations is an effective way to change these properties [4-9]. When metal ions are incorporated in BaM compound, its saturation magnetization, coercivity and anisotropy field depend on the nature, combination and distribution of this substitution in Fe sublattices.

The aim of the present work is to study the chemical changes that can be induced by the nature and distribution of the trivalent ion in barium hexaferrite and the resulting 
magnetic properties. Two species of trivalent ions are selected, nonmagnetic ions $\mathrm{Al}^{3+}$, $\mathrm{Bi}^{3+}$ and magnetic ions $\mathrm{Cr}^{3+}, \mathrm{Mn}^{3+}$ ions for $\mathrm{Fe}^{3+}$ substitution within $\mathrm{BaFe}_{12} \mathrm{O}_{19}$ compound. To examine the influence of the incorporation of each substitution on BaM ferrite and find out the chemical structure modifications, X-ray diffraction, FTIR spectroscopy, SEM and EDX analysis are used. The effects of the trivalent ions substitution and its correlation with magnetic behaviour of these hexaferrites are then investigated.

\section{Experimental}

\subsection{Chemicals}

Starting materials $\mathrm{Fe}\left(\mathrm{NO}_{3}\right)_{3} \cdot 9 \mathrm{H}_{2} \mathrm{O}, \quad \mathrm{Ba}\left(\mathrm{NO}_{3}\right)_{2}, \quad \mathrm{Al}\left(\mathrm{NO}_{3}\right)_{3} .9 \mathrm{H}_{2} \mathrm{O}, \quad \mathrm{Bi}\left(\mathrm{NO}_{3}\right)_{3} .5 \mathrm{H}_{2} \mathrm{O}$, $\mathrm{Cr}\left(\mathrm{NO}_{3}\right)_{3} \cdot 9 \mathrm{H}_{2} \mathrm{O}, \quad \mathrm{Mn}\left(\mathrm{NO}_{3}\right)_{2} \cdot 4 \mathrm{H}_{2} \mathrm{O}$ and $\mathrm{NaOH}$ used as such without any further treatment, for the synthesis of different samples, are purchased from Sigma-Aldrich.

\subsection{Material preparation}

Samples of $\mathrm{BaMeFe}{ }_{11} \mathrm{O}_{19}(M e=\mathrm{Al}, \mathrm{Bi}, \mathrm{Cr}$ and $\mathrm{Mn})$ hexaferrites are prepared by dynamic hydrothermal method. Appropriate amount of $\mathrm{Fe}\left(\mathrm{NO}_{3}\right)_{3} \cdot 9 \mathrm{H}_{2} \mathrm{O}, \mathrm{Ba}\left(\mathrm{NO}_{3}\right)_{2}$, $\mathrm{Al}\left(\mathrm{NO}_{3}\right)_{3} .9 \mathrm{H}_{2} \mathrm{O}$ or $\mathrm{Bi}\left(\mathrm{NO}_{3}\right)_{3} .5 \mathrm{H}_{2} \mathrm{O}$ or $\mathrm{Cr}\left(\mathrm{NO}_{3}\right)_{3} .9 \mathrm{H}_{2} \mathrm{O}$ or $\mathrm{Mn}\left(\mathrm{NO}_{3}\right)_{2} .4 \mathrm{H}_{2} \mathrm{O}$ are mixed with 2.5 mol. $\mathrm{L}^{-1} \mathrm{NaOH}$ solution according to desired stoichiometries, at room temperature and under magnetic stirring. The resulting solution is poured into teflonlined stainless steel autoclave which is sealed, then placed in a shaked furnace. The autoclave is maintained at $220{ }^{\circ} \mathrm{C}$ for $8 \mathrm{~h}$, then cooled down to room temperature. The obtained products are filtered, washed several times with distilled water and finally dried in an oven at $80{ }^{\circ} \mathrm{C}$. 
The processed powders are calcined in air in the temperature range from $900{ }^{\circ} \mathrm{C}$ to $1000{ }^{\circ} \mathrm{C}$ for $2 \mathrm{~h}$ with heating rate of $10{ }^{\circ} \mathrm{C} \cdot \mathrm{min}^{-1}$. The details of different samples are summarized in Table 1.

\subsection{Characterization}

The phase composition and structure of the synthesized samples are examined using PANalytical X'Pert Pro diffractometer with Cobalt $\mathrm{K} \alpha$ radiation $(\lambda=1.79 \AA)$ in the range of $10^{\circ} \leq 2 \theta \leq 80^{\circ}$ with $0.02^{\circ}$ step size. Crystal structure and microstructure are refined applying Rietveld method using MAUD software [10]. Structural parameters such as lattice constants ( $a$ and $c$ ) and crystallite size $D$ are obtained from Rietveld analysis. The unit volume cell $V$ and X-ray density $\rho_{\mathrm{XRD}}$ of the prepared samples are calculated by the following equations

$$
\begin{aligned}
V & =\frac{\sqrt{3}}{2} a^{2} c \\
\rho_{X R D} & =\frac{Z M}{N_{A} V}
\end{aligned}
$$

where $d$ is the distance between lattice planes and $(h, k, l)$ Miller indices, $Z$ the number of formula units in a cell, $\mathrm{M}$ the molar mass of the sample and $N_{A}$ Avogadro number. Infrared spectra of different samples are obtained on a Thermo Electron Corporation Nicolet Nexus 670 FTIR Spectrometer, collecting 64 scan in the range of $4000-400 \mathrm{~cm}^{-1}$, with $4 \mathrm{~cm}^{-1}$ resolution at room temperature. The surface morphology and EDX analysis are studied using scanning electron microscope (SEM) Hitachi S-3400N model equipped with TEAM ${ }^{\mathrm{TM}}$ EDX system for elemental microanalysis. The spectra of the samples are collected by smart phase mapping to provide high level of elemental analysis. Magnetic measurements, such as saturation magnetization Ms, 
remanent magnetization $\mathrm{Mr}$, coercivity $\mathrm{Hc}$ and Curie temperature $\mathrm{Tc}$ are made on Lake Shore 7400 vibrating sample magnetometer (VSM).

3. Results and discussion

\subsection{X-ray structure analysis}

The powder X-ray diffraction patterns of $\mathrm{BaMeFe}_{11} \mathrm{O}_{19}$ samples with $\mathrm{Me}=\mathrm{Al}, \mathrm{Bi}, \mathrm{Cr}$ and $\mathrm{Mn}$ annealed at $900,950,1000{ }^{\circ} \mathrm{C}$ are presented in Fig. 1. All the sharp reflection peaks are indexed corresponding to the standard data obtained from M-type barium hexaferrite ICDD pattern No. 74-1121 within space group P63/mmc. For different samples, $\mathrm{BaFe}_{12} \mathrm{O}_{19}$ phase is formed at $900{ }^{\circ} \mathrm{C}$ together with other secondary phases. The amount of the main phase increases with increasing temperature, while other phases decease or disappear.

Lattice parameters $(a$ and $c)$, crystallite size $(D)$ and the X-ray density $\left(\rho_{X R D}\right)$ of the substituted hexaferrites are calculated and their values are listed in Table 2. It can be seen that with increasing calcination temperature from 900 to $1000{ }^{\circ} \mathrm{C}$, an increase of crystallite size is induced. The X-ray density decreased for $\mathrm{BaAlFe}_{11} \mathrm{O}_{19}, \mathrm{BaCrFe}_{11} \mathrm{O}_{19}$ and $\mathrm{BaMnFe}_{11} \mathrm{O}_{19}$, whereas, it increased for $\mathrm{BaBiFe}_{11} \mathrm{O}_{19}$ since it is related to the molecular weight.

As shown in Table 2, lattice constants of the hexaferrite samples are affected by radius of the substitution ion. In fact, for $\mathrm{BaAlFe}_{11} \mathrm{O}_{19}, \mathrm{BaCrFe}_{11} \mathrm{O}_{19}$ and $\mathrm{BaMnFe}_{11} \mathrm{O}_{19}$ ferrite, $a$ and $c$ are similar to those of $\mathrm{BaFe}_{12} \mathrm{O}_{19}$ as the ionic radius values of $\mathrm{Al}^{3+}, \mathrm{Cr}^{3+}$ and $\mathrm{Mn}^{3+}$ are close to that of $\mathrm{Fe}^{3+}$ (see Table 3, $[11,12]$ ), so, it is easier to substitute in the lattice of barium ferrite [13-16]. However, they did not change with bismuth substitution as it is thought. Actually, it is supposed that $\mathrm{Bi}^{3+}$ (radius $=96 \mathrm{pm}$ ) could be 
oxidized to $\mathrm{Bi}^{5+}$ (radius $=74 \mathrm{pm}$ ), to substitute the $\mathrm{Fe}^{3+}$ ions (radius $=67 \mathrm{pm}$ ) in hexagonal phase. As $\mathrm{Bi}^{3+}$ cation is unstable in $\mathrm{Fe}^{3+}$ sites, the following chemical reaction may result:

$$
\mathrm{Bi}^{3+}+2 \mathrm{Fe}^{3+} \longrightarrow \mathrm{Bi}^{5+}+2 \mathrm{Fe}^{2+}
$$

So, for each $\mathrm{Bi}^{5+}$ entering the lattice two $\mathrm{Fe}^{2+}$ are formed [17].

\subsection{Infrared analysis}

The formation of the hexagonal structure of substituted barium ferrite is also investigated by infrared analysis. Typical FTIR spectra of $\mathrm{BaFe}_{12} \mathrm{O}_{19}, \mathrm{Al1000,} \mathrm{Bi1000}$, Cr1000 and Mn1000 are shown in Fig. 2. For all samples, the spectra indicate the presence of absorption bands in the range of 400 to $800 \mathrm{~cm}^{-1}$ which are a common feature of the hexaferrites [18]. The lower frequency absorption band $v_{1}$ between 400 and $490 \mathrm{~cm}^{-1}$ is assigned to $\mathrm{Fe}-\mathrm{O}$ bending vibration of octahedral site and the higher frequency absorption band $v_{2}$ lying in the range of 500 to $600 \mathrm{~cm}^{-1}$ is related to $\mathrm{Fe}-\mathrm{O}$ stretching vibration in the tetrahedral site [19]. The $v_{1}$ and $v_{2}$ bands continuously increase with annealing temperature from $900{ }^{\circ} \mathrm{C}$ to $1000{ }^{\circ} \mathrm{C}$ which reflect the presence of high degree of crystallinity. No other band is observed, suggesting that single $\mathrm{BaFe}_{12} \mathrm{O}_{19}$ phase is obtained which is in agreement with XRD characterization. For pure hexaferrite, the remarkable absorption peak at $545 \mathrm{~cm}^{-1}$ is associated to Ba-O stretching vibration band [20]. This peak is less observed in the substituted ferrites, since it is overlapped with the characteristic bands $\left(v_{1}\right.$ and $\left.v_{2}\right)$ of hexaferrite [21]. The bands in the range of $1000-1700 \mathrm{~cm}^{-1}$ are associated to Metal-Oxygen-Metal bands [22], whereas, the broad band around $3400 \mathrm{~cm}^{-1}$ is due to the adsorbed water molecules. For pure $\mathrm{BaFe}_{12} \mathrm{O}_{19}$, it can be observed that there is an even distribution of iron ions in the two 
sites since the absorbance of $v_{1}$ and $v_{2}$ bands are alike. This tendency changes with substituted hexaferrites. For aluminium, chromium and manganese substitution, absorbance of stretching vibration in the tetrahedral site $v_{2}$ becomes greater than that of bending vibration of octahedral site $v_{1}$, however, the absorbance of $v_{2}$ is lower than that of $v_{1}$ for $\mathrm{BaBiFe}_{11} \mathrm{O}_{19}$, independently of the calcination temperature. This phenomenon can be related to the mass of the atoms since heavier atoms vibrate slower than lighter ones, so Me-O band will vibrate at a lower frequency therefore the stretching absorption will be decreased for bismuth compared to other hexaferrites. Other reason may be related to the radius of trivalent ion. In fact, $\mathrm{Al}^{3+}, \mathrm{Cr}^{3+}$ and $\mathrm{Mn}^{3+}$ have ionic radius close to that $\mathrm{Fe}^{3+}$, so a tendency to replace the tetrahedral sites except for manganese which can be in all sites. But by examining its IR spectrum, it occupies preferentially the tetrahedral site. $\mathrm{Bi}^{3+}$ with its large radius trends to occupy the octahedral site, as seen from lattice parameters determined from XRD study. So, increasing bending vibration of this site by bismuth increased its dimension, so its absorbance [23].

\subsection{Morphological analysis}

The surface morphology and microstructure of Al1000, Bi1000, Cr1000 and Mn1000 are observed by scanning electron microscopy (SEM) as depicted in Fig. 3. Agglomerated hexagonal shaped particles can be observed in all four samples. Bi1000 reveals small spherical shaped-particles with a size about $400 \pm 50 \mathrm{~nm}$, meanwhile, Al1000, Cr1000 and Mn1000 presented bigger hexagonal shaped-particles with an average grain size in the range of $1-2 \mu \mathrm{m}$. The observed $\mathrm{BaBiFe}_{11} \mathrm{O}_{19}$ morphology is associated to of $\mathrm{Bi}^{3+}$ substitution which promotes the formation of homogeneous spherical shapes, as it has been already reported [24]. 
The energy dispersive X-ray analysis (EDX) is carried out in order to confirm the chemical composition of the substituted hexaferrites. Fig. 4 shows the typical EDX spectra of substituted barium hexaferrite calcined at $1000{ }^{\circ} \mathrm{C}$. The analysis data is collected in a table as inset in the same figure. The difference between the data in the two columns is discussed according to the atomic number of each element [25].

The estimated atomic percentages for different atoms basically agree with the designed composition. It is observed that the elements $\mathrm{Ba}, \mathrm{Fe}, \mathrm{O}$ and substituting trivalent ion are evenly distributed throughout the whole area, revealing a uniform chemical phase. The determined atomic ratio of $\mathrm{Al}, \mathrm{Cr}, \mathrm{Bi}$ and $\mathrm{Mn}$ to $\mathrm{Fe}$ is $0.120,0.066,0.09$ and 0.106, respectively, which is close to the nominal value of 0.09 and within the uncertainty of the instrument.

\subsection{Magnetic analysis}

The room temperature magnetic hysteresis loops $(\mathrm{M}-\mathrm{H})$ of $\mathrm{BaFe}_{12} \mathrm{O}_{19}$ and $\mathrm{BaMeFe}{ }_{11} \mathrm{O}_{19}$ $(M e=\mathrm{Al}, \mathrm{Bi}, \mathrm{Cr}$ and $\mathrm{Mn})$ samples annealed at 900,950 and $1000{ }^{\circ} \mathrm{C}$ for $2 \mathrm{~h}$ are shown in Fig. 6 and 7. The measured values of coercivity Hc, saturation magnetization Ms and remanent magnetization $\mathrm{Mr}$ are given in Table 4. According to ferromagnetic theory, magnetism in ferrites originates from the magnetic moments of ions in spin up and spin down orientations in sublattice [26]. Usually, the magnetic behaviour of the M-type hexaferrite is related to the distribution of iron ions in the crystallographic lattice sites. The $\mathrm{Fe}^{3+}$ ions are spread over five crystallographic sites: three octahedral sites $12 \mathrm{k}$ (spin up), 2a (spin up), and $4 f_{2}$ (spin down), one tetrahedral $4 f_{1}$ (spin down) and one bipyramidal $2 \mathrm{~b}$ (spin up) as shown in Fig. 5 [27]. The magnetic moment of barium hexaferrite is deduced from the algebraic sum of iron magnetic moments in different positions according to [28] 


$$
M=M(12 k+2 b+2 a) \uparrow-M\left(4 f_{1}+4 f_{2}\right) \downarrow
$$

For undoped $\mathrm{BaFe}_{12} \mathrm{O}_{19}$, as the magnetic moment of $\mathrm{Fe}^{3+}$ is $5 \mu_{\mathrm{B}}$, the resulting magnetic moment is equal to $20 \mu_{\mathrm{B}}$ per unit formula leading to a magnetic moment of $40 \mu_{\mathrm{B}}$ per unit cell.

As observed in Fig. 7 and Table 4, the obtained samples have a ferromagnetic behaviour with magnetic properties affected by magnetic nature of trivalent ion substitutions and their occupied position in the five different lattice sites of $\mathrm{Fe}^{3+}$. For non-magnetic substitution by $\mathrm{Al}^{3+}$ and $\mathrm{Bi}^{3+}$ ions, a significant reduction of $\mathrm{Ms}$ and $\mathrm{Mr}$ can be observed. $\mathrm{Al}^{3+}$ ions preferentially occupy the octahedral sites $12 \mathrm{k}$ (upward) [29, 30]. This preferential occupation results in a reduction of saturation magnetization. Bismuth atoms seek to replace $4 \mathrm{f}_{1}$ tetrahedral sites. As it is already discussed in XRD and FTIR section, $\mathrm{Bi}^{3+}$ is unstable in $\mathrm{Fe}^{3+}$ sites and can be oxidized to $\mathrm{Bi}^{5+}$ to enter the lattice [31, 32]. Consequently, two $\mathrm{Fe}^{2+}$ can be formed resulting in a decrease of Ms.

In case of magnetic substitution by $\mathrm{Cr}^{3+}$ and $\mathrm{Mn}^{3+}$ ions, the increase of $\mathrm{Ms}$ and $\mathrm{Mr}$ with calcination temperature is due to the decrease or disappearance of secondary phase as shown in X-ray diffraction patterns in Fig. 1. c. At calcination temperature higher than $900^{\circ} \mathrm{C}$, no significant decrease in $\mathrm{Ms}$ and $\mathrm{Mr}$ values is observed compared to those of pure hexaferrite. As reported in the literature, $\mathrm{Cr}^{3+}$ with $3 \mu_{\mathrm{B}}$, at high substitution level $(>0.4)$, preferentially occupies $12 \mathrm{k}$ and $2 \mathrm{a}$ octahedral sites where it replaces $\mathrm{Fe}^{3+}[33$, 34]. Consequently, the magnetic moment per formula unit $M$ decreases which explains the observed slight decrease of magnetization. In manganese substituted $\mathrm{BaM}, \mathrm{Mn}^{3+}$ ions may substitute the $\mathrm{Fe}^{3+}$ ions in all sites: $12 \mathrm{k}, 2 \mathrm{a}, 2 \mathrm{~b}$ (spin up) or $4 \mathrm{f}_{1}, 4 \mathrm{f}_{2}$ ( pin down) $[35,36]$. The replacement of $\mathrm{Fe}^{3+}$ by $\mathrm{Mn}^{3+}$ ions does not alter the saturation 
magnetization because both have the same magnetic moment (as shown in Table 3, [37]).

Table 4 shows the variation of coercivity of doped barium hexaferrites upon annealing temperature and ion substitution. The substituted samples have larger coercivity than pure $\mathrm{BaFe}_{12} \mathrm{O}_{19} \quad(0.241 \mathrm{~T})$ which decreases with annealing temperature. The enhancement in coercivity is due partially to the smaller crystallite size [38]. As seen in XRD study, the $D$ value of barium hexaferrite is reduced with the substitution (Table 1), but this fact alone cannot explain enhancement of $\mathrm{Hc}$ in $\mathrm{Mn}$ and Bi substituted samples. As $\mathrm{Mn}^{3+}$ and $\mathrm{Fe}^{2+}$ (induced by $\mathrm{Bi}^{5+}$ ) are in the electronic configuration $3 \mathrm{~d}^{4}$ and $3 \mathrm{~d}^{6}$, respectively, they may bring significant orbital moment and contribute to the increase magnetorystalline anisotropy.

In order to determine the efficiency of a magnetic material, maximum energy product $(\mathrm{BH})_{\max }$ is calculated using the magnetic data [39]. The evolution of $(\mathrm{BH})_{\max }$ with substitution ions and calcination temperature is presented in Fig. 8. An increase of magnetic energy is well observed with increasing calcination temperature for all substituted barium ferrites except for $\mathrm{BaBiFe}_{11} \mathrm{O}_{19}$ which displays a remarkable decrease. It is also noted that the behaviour of $(\mathrm{BH})_{\max }$ is related to the magnetic moment of trivalent ion. In fact, among magnetic ion substitutions, barium hexaferrite substituted with manganese $\left(5 \mu_{\mathrm{B}}\right)$ reveals the highest energy product with $7.47 \mathrm{~kJ} . \mathrm{m}^{-3}$, meanwhile, for nonmagnetic ion substitutions, Aluminium substitution $\left(0 \mu_{\mathrm{B}}\right)$ presents the lowest $(\mathrm{BH})_{\max }$ with $4.40 \mathrm{~kJ} \cdot \mathrm{m}^{-3}$, at $1000^{\circ} \mathrm{C}$.

The maximum energy product reduction of bismuth substitution can be associated with the presence of the distortion created by two-steps hysteresis loop at all annealing 
temperatures (Fig. 7. b) which is not due to the presence of secondary phase, as confirmed by XRD and FTIR data.

\subsection{Curie point measurement}

In order to figure out Curie temperature $\left(T_{c}\right)$ of different substituted barium hexaferrites, temperature dependence of magnetization is measured using VSM with high temperature attachment. The magnetization of the samples is determined in the temperature range of $25-550{ }^{\circ} \mathrm{C}$ in an applied field of $1 \mathrm{~T}$. Magnetization as function of temperature for different substitutions is shown in Fig. 9.

As it is clearly seen from the data, for all substituted ferrites, only one ferromagnetic paramagnetic phase transition is observed which suggests the presence of single phase material as already indicated by diffraction patterns and infrared results. As presented in Table 5, $\mathrm{T}_{\mathrm{c}}$ of $\mathrm{BaFe}_{12} \mathrm{O}_{19}$ is found to be $457{ }^{\circ} \mathrm{C}$ which is close to the value of $473{ }^{\circ} \mathrm{C}$ reported by Smit and Wijn [1]. It is interesting to note that Curie temperatures of $\mathrm{Al}, \mathrm{Cr}$ and $\mathrm{Bi}$ doped hexaferrite sample are higher than that of pure $\mathrm{BaFe}_{12} \mathrm{O}_{19}$, whereas, $\mathrm{BaMnFe}_{11} \mathrm{O}_{19}$ revealed a lower Tc corresponding (Table 5). The change in Curie temperature is ascribed to the modification of the exchange strength of octahedral and tetrahedral interactions as consequence of a change of the trivalent ion distribution between these two sites [40].

From ions distribution, it is expected for $\mathrm{Al}^{3+}, \mathrm{Bi}^{3+}$ and $\mathrm{Cr}^{3+}$ substitution with low magnetic moment replacing $\mathrm{Fe}^{3+}$ to decrease the strength of octahedral and tetrahedral interactions leading to decrease of Tc. However, Tc is found to increase. This can be attributed to the big ionic radius of aluminium, bismuth and chromium causing the distortion of lattice sites which is directly proportional to interionic distances. This 
distortion leads to greater cation-anion-cation bond angles and strengthening of sites exchange interactions [41].

In the manganese substituted ferrite, the reduction of Curie temperature shown in Fig. 9 and Table 5, can be explained by the distribution of manganese ions over octahedral and tetrahedral sites. Producing, a shift of Curie temperature towards lower temperature, as observed in manganese substituted spinels and W-hexaferrites [1].

\section{Conclusion}

M-type hexaferrites $\mathrm{BaMeFe}{ }_{11} \mathrm{O}_{19}$ substituted with trivalent nonmagnetic ions $\left(\mathrm{Al}^{3+}\right.$, $\left.\mathrm{Bi}^{3+}\right)$ and magnetic ions $\left(\mathrm{Cr}^{3+}, \mathrm{Mn}^{3+}\right)$ are successfully synthesized by dynamic hydrothermal technique. The XRD and FTIR analysis confirmed the formation of single phase hexagonal structure for all hexaferrites. Morphological investigation revealed small spherical-shaped particles $(400 \pm 50 \mathrm{~nm})$ for Bi substitution and hexagonalshaped particles (1-2 $\mu \mathrm{m})$ for $\mathrm{Al}, \mathrm{Cr}$ and Mn substitutions. The elemental study obtained from EDX analysis gave a uniform chemical composition for all samples. The magnetic study indicated that magnetic parameters markedly depend on the nature, concentration and distribution of doped ions on the five sites in the crystal lattice. The saturation magnetization decreased and the coercive field increased with nonmagnetic Al substitution as it preferred to occupy $12 \mathrm{k}$ sites. FTIR, DRX and magnetic characterization revealed that bismuth ions substituted iron ions at octahedral sites resulting to valence variation of $\mathrm{Bi}^{3+}$ to $\mathrm{Bi}^{5+}$ and $\mathrm{Fe}^{3+}$ to $\mathrm{Fe}^{2+}$ cations in the hexagonal structure which contributed to the modification of the magnetorystalline anisotropy, as seen from hysteresis loops. The magnetic properties $\left(\mathrm{Ms}, \mathrm{Mr}\right.$ and $\mathrm{Hc}$ and $\left.(\mathrm{BH})_{\max }\right)$ of the hexaferrites decreased with nonmagnetic trivalent ions $\left(\mathrm{Al}^{3+}, \mathrm{Bi}^{3+}\right)$ substitution and 
increased with magnetic ions $\left(\mathrm{Cr}^{3+}, \mathrm{Mn}^{3+}\right)$ substitution compared to pure $\mathrm{BaFe}_{12} \mathrm{O}_{19}$. Manganese ions, on other hand, replaced the $\mathrm{Fe}^{3+}$ ions in all five sites contributing to reach the maximum values of magnetization $(\mathrm{Ms}=61.10 \mathrm{emu} / \mathrm{g})$, remanence $(\mathrm{Mr}=33.16 \mathrm{emu} / \mathrm{g})$ coercivity $(\mathrm{Hc}=0.430 \mathrm{~T})$ inducing a greater maximum energy product $\left((\mathrm{BH})_{\max }=7.47 \mathrm{~kJ} \cdot \mathrm{m}^{-3}\right)$. Accordingly, the substitution of $\mathrm{Fe}^{3+}$ by these trivalent ions at different sites is found to be affected by hydrothermal synthesis.

\section{Acknowledgements}

Authors are thankful to Université de Tunis El Manar, Tunis for the financial support to achieve this work and grateful for the funding obtained in the framework of scholarship for international students at SATIE, ENS de Cachan for 12 months.

\section{References}

[1] N.A. Spaldin, Magnetic materials fundamentals and applications, second edition, University press, The Edinburgh Building, Cambridge, (2010).

[2] C. Heck, Magnetic materials and their applications, $1^{\text {st }}$ edition, Butterworths and co, England, (1974).

[3] R.C. Pullar, Hexagonal ferrites: a review of the synthesis, properties and applications of hexaferrite ceramics, Prog. Mater. Sci. 57 (2012) 1191-1334.

[4] L.A. Bashkirov, Yu. L Kostyushko, Formation of ferrite-chromites $\mathrm{BaFe}_{10} \mathrm{Cr}_{2} \mathrm{O}_{19}$ and $\mathrm{SrFe}_{10} \mathrm{Cr}_{2} \mathrm{O}_{19}$ in the solid-phase reaction of $\mathrm{Fe}_{2} \mathrm{O}_{3}$ and $\mathrm{Cr}_{2} \mathrm{O}_{3}$ with barium or strontium carbonate, Russ J. Appl. Chem. 78 (2005) 351-355.

[5] Y. Liu, M.G.B. Drew, J. Wang, M. Zhang, Y. Liu, Efficiency and purity control in the preparation of pure and/or aluminum-doped barium ferrites by hydrothermal methods using ferrous ions as reactants ,J. Magn. Magn. Mater. 322 (2010) 366-374. 
[6] N.J. Shirtcliffe, S. Thompson, E.S. O’Keefe, S. Appleton, C.C. Perry, Highly aluminium doped barium and strontium ferrite nanoparticles prepared by citrate autocombustion synthesis, Mater. Res. Bull. 42 (2007) 281-287.

[7] M.V. Rane, D. Bahadur, S.K. Mandal, M.J. Patni, Characterization of $\mathrm{BaFe}_{12-}$ ${ }_{2 \mathrm{x}} \mathrm{Co}_{\mathrm{x}} \mathrm{Zr}_{\mathrm{x}} \mathrm{O}_{19}(0 \leq \mathrm{x} \leq 0.5)$ synthesised by citrate gel precursor route, J. Magn. Magn. Mater. 153 (1996) L1-L4.

[8] H. Yamamoto, M. Isono, T. Kobayashi, Magnetic properties of Ba-Nd-Co system M-type ferrite fine particles prepared by controlling the chemical coprecipitation method, J. Magn. Magn. Mater. 295 (2005) 51-56.

[9] C.A. Stergiou, I. Manolakis, T.V. Yioultsis, G. Litsardakis, Dielectric and magnetic properties of new rare-earth substituted Ba-hexaferrites in the $2-18 \mathrm{GHz}$ frequency range, J. Magn. Magn. Mater. 322 (2010) 1532-1535.

[10] M. Ferrari, L. Lutterotti, Method for the simultaneous determination of anisotropic residual stresses and texture by X-ray diffraction, J. Appl. Phys. 76 ( 1994) 7246-7255. [11] R. D. Shannon, Revised effective ionic radii and systematic studies of interatomic distances in halides and chalcogenides, Acta Cryst. (1976) 751-767.

[12] Y.Q. Jia, Crystal radii and effective ionic radii of the rare earth ions, J. Solid State Chem. 95 (1991) 184-187.

[13] J. Qiu, M. Gu, H. Shen, Microwave absorption properties of Al- and Cr-substituted M-type barium hexaferrite, J. Magn. Magn. Mater. 295 (2005) 263-268.

[14] Q. Fang, H. Ceng, K. Huang, J. Wang, R. Li, Y. Jiao, Doping effect on crystal structure and magnetic properties of chromium-substituted strontium hexaferrite nanoparticles, J. Magn. Magn. Mater. 294 (2005) 281-286. 
[15] I.K. Lee, J.C. Sur, I.B. Shim, C.S. Kim, The effect of manganese substituted Mtype hexagonal Ba-ferrite, J. Magnetics 14 (2009) 93-96.

[16] G. Asghar, M. Anis-ur-Rehman, Structural, dielectric and magnetic properties of $\mathrm{Cr}-\mathrm{Zn}$ doped strontium hexa-ferrites for high frequency applications, J. Ally. Compd. 526 (2012) 85-90.

[17] M. Pal, P. Brahma, D. Chakravorty, D.C. Agrawal, Magnetic properties of Ba hexaferrites doped with bismuth oxide, J. Magn. Magn. Mater. 147 (1995) 208-212.

[18] F.M.M. Pereira, C.A.R Junior, M.R.P. Santos, R.S.T.M. Sohn, F.N.A. Freire, J.M. Sasaki, J.A.C. De Paiva, A.S.B. Sombra, Structural and dielectric spectroscopy studies of the M-type barium strontium hexaferrite alloys $\left(\mathrm{Ba}_{\mathrm{x}} \mathrm{Sr}_{1-\mathrm{x}} \mathrm{Fe}_{12} \mathrm{O}_{19}\right)$, J. Mater. Sci. Mater. Electron. 19 (2008) 627-638.

[19] Z. Mosleh, P. Kamelin, M. Ranjbar, H. Salamati, Effect of annealing temperature on structural and magnetic properties of $\mathrm{BaFe}_{12} \mathrm{O}_{19}$ hexaferrite nanoparticles, Ceram. Int. 40 (2014) 7279-7284.

[20] X. Tang, B.Y. Zhao, K.A. Hu, Preparation of M-Ba-ferrite fine powders by sugarnitrates process, J. Mater. Sci. 41 (2004) 3867-3871.

[21] G.R. Gordani, A. Ghasemi, A. Saidi, Enhanced magnetic properties of substituted Sr-hexaferrite nanoparticles synthesized by co-precipitation method, Ceram. Int. 40 (2014) 4945-4952.

[22] S. Singhal, T. Namgyal, J. Singh, K. Chandra, S. Bansal, A comparative study on the magnetic properties of $\mathrm{MFe}_{12} \mathrm{O}_{19}$ and $\mathrm{MAlFe}_{11} \mathrm{O}_{19}(\mathrm{M}=\mathrm{Sr}$, $\mathrm{Ba}$ and $\mathrm{Pb})$ hexaferrites with different morphologies, Ceram. Int. 37 (2011) 1833-1837.

[23] S. Ram, Observation of enhanced dielectric permittivity in $\mathrm{Bi}^{3+}$ doped $\mathrm{BaFe}_{12} \mathrm{O}_{19}, \mathrm{j}$. Magn. Magn. Mater. 80 (1989) 241-245. 
[24] M.M. Eltabeya, W.R. Agamic, H.T. Mohsenb, Improvement of the magnetic properties for $\mathrm{Mn}-\mathrm{Ni}-\mathrm{Zn}$ ferrites by rare earth $\mathrm{Nd}^{3+}$ ion substitution, J. Adv. Res. 5 (2014) 601-605

[25] L. Qiao, B, Xu, Q. Xi, J. Zheng, L. Jiang, Effects of trace of $\mathrm{Bi}_{2} \mathrm{O}_{3}$ addition on the morphology of strontium ferrite particles, Ceram, Int. 36 (2010) 1423-1427.

[26] L. Néel, Magnetic properties of ferrites: ferrimagnetism and anti-ferromagnetism, Ann. Phys. Paris 3 (1948) 137-198.

[27] J. Smit, H.P.J. Wijn, Intrinsic properties of ferrites with hexagonal crystal structure, Chapter IX, in Ferrites, N.V Philips' Gloeilampenfabrieken, Eindhoven (Holland), (1959), 177-211.

[28]A. Ghasemi, A. Morisako, Static and high frequency magnetic properties of MnCo-Zr substituted Ba-ferrite, J. Alloy. Compd. 456 (2008) 485-491.

[29] M.N. Ashiq, M.J. Iqbal, I.H. Gul, Effect of Al-Cr doping on the structural, magnetic and dielectric properties of strontium hexaferrite nanomaterials, J. Magn. Magn. Mater. 323 (2011) 259-263.

[30] H.Z. Wanga, B. Yaoa, Y. Xua, Q. Hea, G.H. Wena, S.W. Longa, J. Fana, G.D. Lib, L. Shanb, B. Liua, L.N. Jianga, L.L. Gaoa, Improvement of the coercivity of strontium hexaferrite induced by substitution of $\mathrm{Al}^{3+}$ ions for $\mathrm{Fe}^{3+}$ ions, J. Ally. Compd. 537 (2012) 43-49

[31] T. Osotchan, S. Thongmee, I.M. Tang, On the coercivity of the Bi-doped Bahexaferrite $\mathrm{BaFe}_{12-\mathrm{x}} \mathrm{Bi}_{\mathrm{x}} \mathrm{O}_{12}$, Thammasa Int. J. Sc .Tech. 4 (1999) 54-58.

[32] Y. Peng, X. Wu, Z. Chen, W. Liu, F. Wang, X. Wang, Z. Feng, Y. Chen, V.G. Harris, $\mathrm{BiFeO}_{3}$ tailored low loss $\mathrm{M}$-type hexaferrite composites having equivalent 
permeability and permittivity for very high frequency applications, J. Ally. Compd. $630(2015) 48-53$

[33] Q. Fang, H. Cheng, K. Huang, J. Wang, R. Li, Y. Jiao, Doping effect on crystal structure and magnetic properties of chromium-substituted strontium hexaferrite nanoparticles, J. Magn. Magn. Mater. 294 (2005) 281-286.

[34] M. Awawdeh, I. Bsoul, S.H. Mahmood, Magnetic properties and Mössbauer spectroscopy on Ga, Al, and Cr substituted hexaferrites, J. Ally. Compd. 585 (2014) $465-473$

[35] H. Fu, H.R. Zhai, Y.C. Zhang, B.X. Gu, J.Y. Li, Magnetic properties of Mn substituted barium ferrite, J. Magn. Magn. Mater. 54-57 (1986) 905-906.

[36] H. Sözeria, H. Deligözb, H. Kavasc, A. Baykald, Magnetic, dielectric and microwave properties of $\mathrm{M}-\mathrm{Ti}$ substituted barium hexaferrites $\left(\mathrm{M}=\mathrm{Mn}^{2+}, \mathrm{Co}^{2+}, \mathrm{Cu}^{2+}\right.$, $\left.\mathrm{Ni}^{2+}, \mathrm{Zn}^{2+}\right)$, Ceram. Int. 40 (2014) 8645-8657.

[37] E. C. Stoner, Magnetism and matter, Methucn and Co., London, (1934).

[38] E.C. Stoner, E.P. Wohlfarth, A mechanism of magnetic hysteresis in heterogeneous alloys, Philos. Trans. Roy. Soc. London Ser. A, Math. Phys. Eng. Sci. 240 (1948) 599642.

[39] J.M.D. Coey, Magnetism and magnetic materials, first edition, Cambridge, University press, New York, (2009).

[40] H. Wijn, Landolt Bornstein III BD, 4b, Springer Verlag, Berlin, Heidelberg, New York, (1970), p.547.

[41] A. Guinier; W.J Duffin, R. Jullien, The solid state from superconductors to superalloys, Oxford: Oxford Univ. Press, (1989). 


\section{Tables}

Table 1 Samples designations

Table 2 Lattice parameters, crystallite size and X-ray density for substituted barium hexaferrites

Table 3 Ionic radii and ionic magnetic moment $\left(\mu_{\mathrm{B}}\right)$ of different used cations for barium ferrite substitutions

Table 4 Magnetic parameters of different substituted Barium hexaferrites

Table 5 Curie temperature of different samples annealed at $950{ }^{\circ} \mathrm{C}$ 
Table 1

\begin{tabular}{lcc}
\hline Sample & Calcination Temperature $\left({ }^{\circ} \mathbf{C}\right)$ & Abbreviation \\
\hline BaAlFe $_{11} \mathbf{O}_{19}$ & 900 & $\mathrm{~A} 1900$ \\
& 950 & $\mathrm{~A} 1950$ \\
BaBiFe $_{11} \mathbf{O}_{19}$ & 1000 & $\mathrm{~A} 11000$ \\
& 900 & $\mathrm{Cr} 900$ \\
$\mathbf{B a C r F e}_{11} \mathbf{O}_{\mathbf{1 9}}$ & 950 & $\mathrm{Cr} 950$ \\
& 1000 & $\mathrm{Cr} 1000$ \\
\hline $\mathbf{B a M n F e}_{11} \mathbf{O}_{\mathbf{1 9}}$ & 900 & $\mathrm{Cr} 900$ \\
& 950 & $\mathrm{Cr} 950$ \\
& 1000 & $\mathrm{Cr} 1000$ \\
\hline
\end{tabular}


Table 2

\begin{tabular}{lllccl}
\hline Sample & $\boldsymbol{a}(\mathbf{n m})$ & $\boldsymbol{c}(\mathbf{n m})$ & $\boldsymbol{c} / \boldsymbol{a}$ & $\boldsymbol{\rho}_{x-\text { ray }}\left(\mathbf{g ~ c m}^{-\mathbf{3}}\right)$ & $\boldsymbol{D}(\mathbf{n m})$ \\
\hline BaFe $_{12} \mathbf{O}_{\mathbf{1 9}}$ & 0.58944 & 2.3231 & 3.9439 & 5.286 & 294.5 \\
\hline Al900 & 0.58965 & 2.3223 & 3.9384 & 5.152 & 160.7 \\
Al950 & 0.58921 & 2.3209 & 3.9390 & 5.150 & 177.9 \\
Al1000 & 0.58917 & 2.3181 & 3.9345 & 5.150 & 183.5 \\
\hline Bi900 & 0.58992 & 2.3210 & 3.9344 & 6.028 & 153.5 \\
Bi950 & 0.58931 & 2.3205 & 3.9376 & 6.063 & 213.2 \\
Bi1000 & 0.58929 & 2.3185 & 3.9343 & 6.063 & 229.8 \\
\hline Cr900 & 0.58992 & 2.3179 & 3.9291 & 5.288 & 198.2 \\
Cr950 & 0.58917 & 2.3195 & 3.9368 & 5.278 & 248.2 \\
Cr1000 & 0.58824 & 2.3212 & 3.9460 & 5.278 & 262.1 \\
\hline Mn900 & 0.58893 & 2.3175 & 3.9351 & 5.295 & 204.9 \\
Mn950 & 0.58909 & 2.3188 & 3.9362 & 5.295 & 207.1 \\
Mn1000 & 0.58924 & 2.3193 & 3.9360 & 5.295 & 215.1 \\
\hline
\end{tabular}


Table 3

\begin{tabular}{lcc}
\hline Ion & Ionic radius $(\mathbf{p m})$ & $\begin{array}{c}\text { Ionic magnetic } \\
\text { moment }\left(\boldsymbol{\mu}_{\mathbf{B}}\right)\end{array}$ \\
\hline $\mathbf{F} \mathbf{e}^{3+}$ & 67 & 5 \\
\hline $\mathbf{F} \mathbf{e}^{2+}$ & 83 & 4 \\
\hline $\mathbf{A l}^{3+}$ & 57 & 0 \\
\hline $\mathbf{B i}^{3+}$ & 96 & 0 \\
\hline $\mathbf{B i}^{5+}$ & 74 & 0 \\
\hline $\mathbf{C r}^{3+}$ & 64 & 3 \\
\hline $\mathbf{M n}$ & 70 & 5 \\
\hline
\end{tabular}


Table 4

\begin{tabular}{lllll}
\hline Composition & $\boldsymbol{\mu}_{\mathbf{0}} \mathbf{H c}(\mathbf{T})$ & Ms $(\mathbf{e m u} / \mathbf{g})$ & $\mathbf{M r}(\mathbf{e m u} / \mathbf{g})$ & $\mathbf{M r} / \mathbf{M s}$ \\
\hline BaFe $_{12} \mathbf{O}_{19}$ & 0.241 & 61.84 & 33.95 & 0.567 \\
Al900 & 0.335 & 51.89 & 28.86 & 0.535 \\
A1950 & 0.329 & 52.86 & 30.05 & 0.538 \\
Al1000 & 0.339 & 54.98 & 32.25 & 0.556 \\
Bi900 & 0.488 & 46.27 & 24.54 & 0.531 \\
Bi950 & 0.481 & 47.72 & 25.43 & 0.530 \\
Bi1000 & 0.376 & 49.50 & 25.84 & 0.522 \\
Cr900 & 0.449 & 36.47 & 19.41 & 0.532 \\
Cr950 & 0.345 & 55.61 & 29.22 & 0.525 \\
Cr1000 & 0.230 & 60.33 & 35.68 & 0.581 \\
Mn900 & 0.434 & 50.16 & 27.96 & 0.546 \\
Mn950 & 0.431 & 51.68 & 28.45 & 0.551 \\
Mn1000 & 0.426 & 61.10 & 33.26 & 0.550 \\
\hline
\end{tabular}


Table 5

\begin{tabular}{ll}
\hline Sample & $\mathbf{T}_{\mathbf{c}}\left({ }^{\circ} \mathbf{C}\right)$ \\
\hline $\mathbf{B a F e}_{12} \mathbf{O}_{19}$ & 457 \\
$\mathbf{B a A l F e}_{11} \mathbf{O}_{19}$ & 485 \\
$\mathbf{B a B i F e}_{11} \mathbf{O}_{19}$ & 478 \\
$\mathbf{B a C r F e}_{11} \mathbf{O}_{19}$ & 479 \\
$\mathbf{B a M n F e}_{11} \mathbf{O}_{19}$ & 424 \\
\hline
\end{tabular}




\section{Figures Captions}

Fig. 1. X-ray diffraction patterns of samples a) $\mathrm{BaAlFe}_{11} \mathrm{O}_{19}$, b) $\mathrm{BaBiFe}_{11} \mathrm{O}_{19}$, c)

$\mathrm{BaCrFe}_{11} \mathrm{O}_{19}$ and d) $\mathrm{BaMnFe}_{11} \mathrm{O}_{19}$ calcined at different temperatures

Fig. 2. FTIR absorption spectra of substituted barium hexaferrite calcined at $1000{ }^{\circ} \mathrm{C}$

Fig. 3. SEM images of a) Al1000, b) Bi1000, c) Cr1000 and d) Mn1000

Fig. 4. EDX patterns for a) Al1000, b) Bi1000, c) Cr1000 and d) Mn1000

Fig. 5. Unit cell of the barium hexaferrite

Fig. 6. Hysteresis curve $(\mathrm{M}-\mathrm{H})$ of $\mathrm{BaFe}_{12} \mathrm{O}_{19}$

Fig. 7. Hysteresis curves (M-H) of a) $\mathrm{BaAlFe}_{11} \mathrm{O}_{19}$. b) $\mathrm{BaBiFe}_{11} \mathrm{O}_{19}$ c) $\mathrm{BaCrFe}_{11} \mathrm{O}_{19}$ and

d) $\mathrm{BaMnFe}_{11} \mathrm{O}_{19}$ calcined at different temperatures

Fig. 8. Variation of $(\mathrm{BH})_{\max }$ with the calcination temperature for different hexaferrite powders

Fig. 9. Magnetization of substituted hexaferrites as function of temperature used to determine the Curie temperature 
Fig. 1.
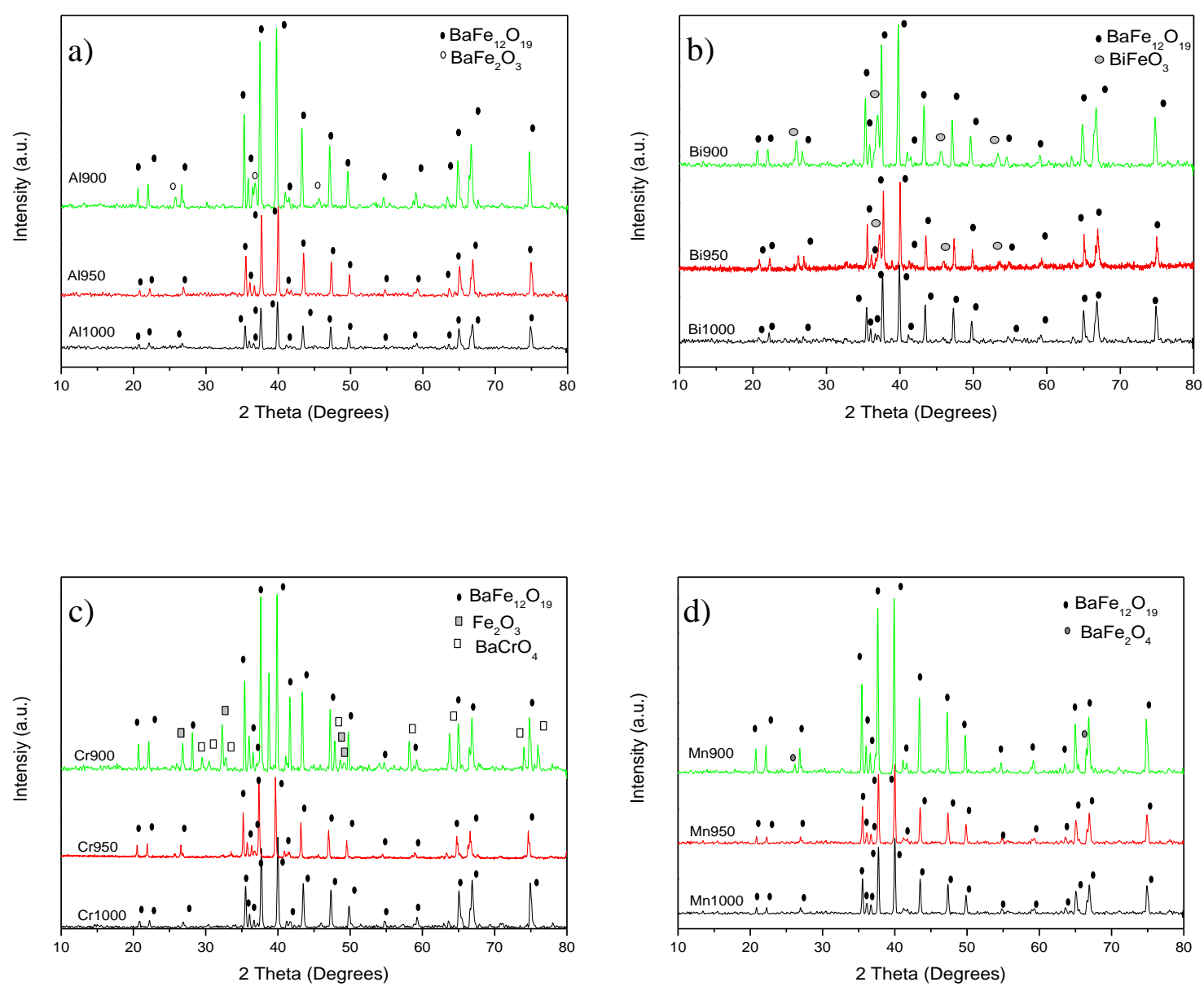
Fig. 2.

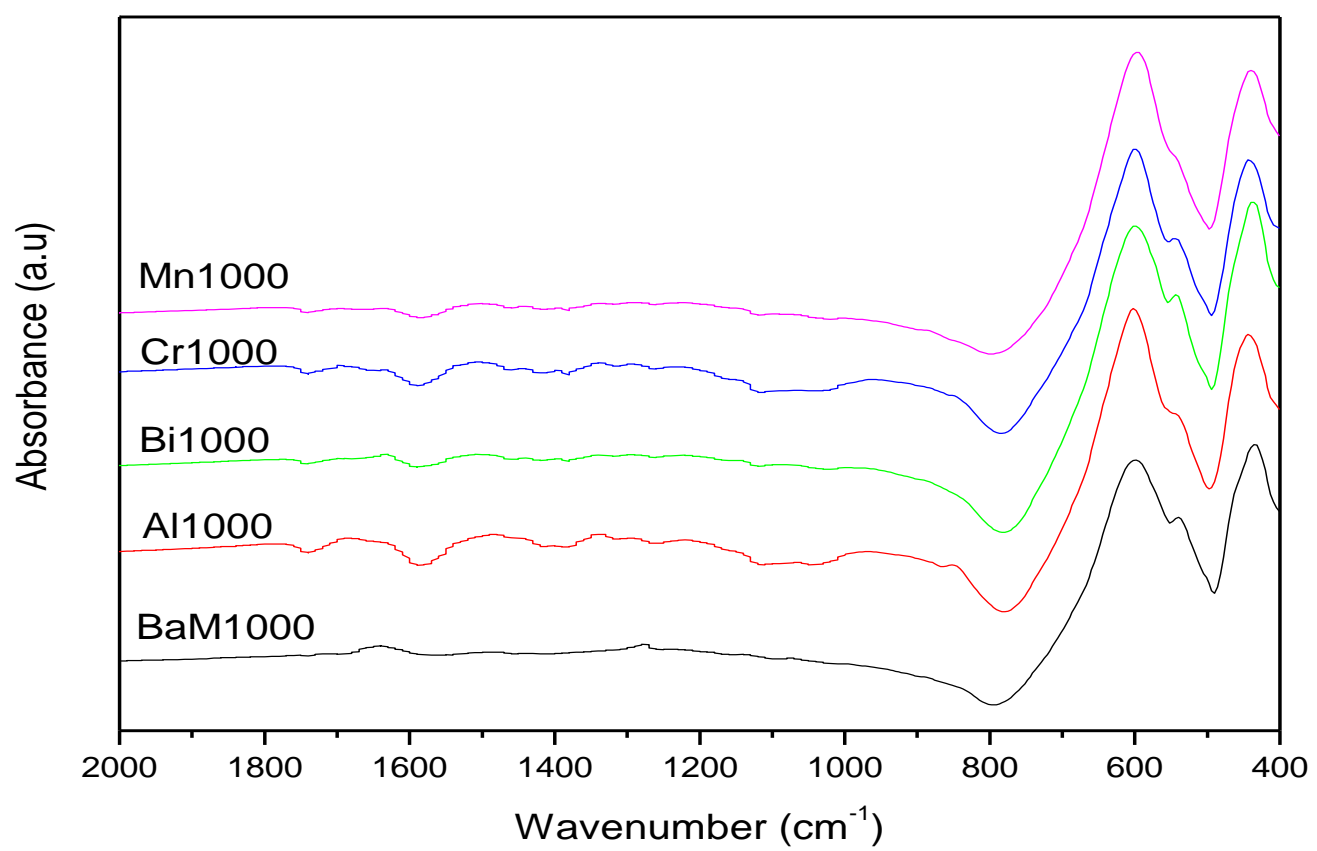


Fig. 3.
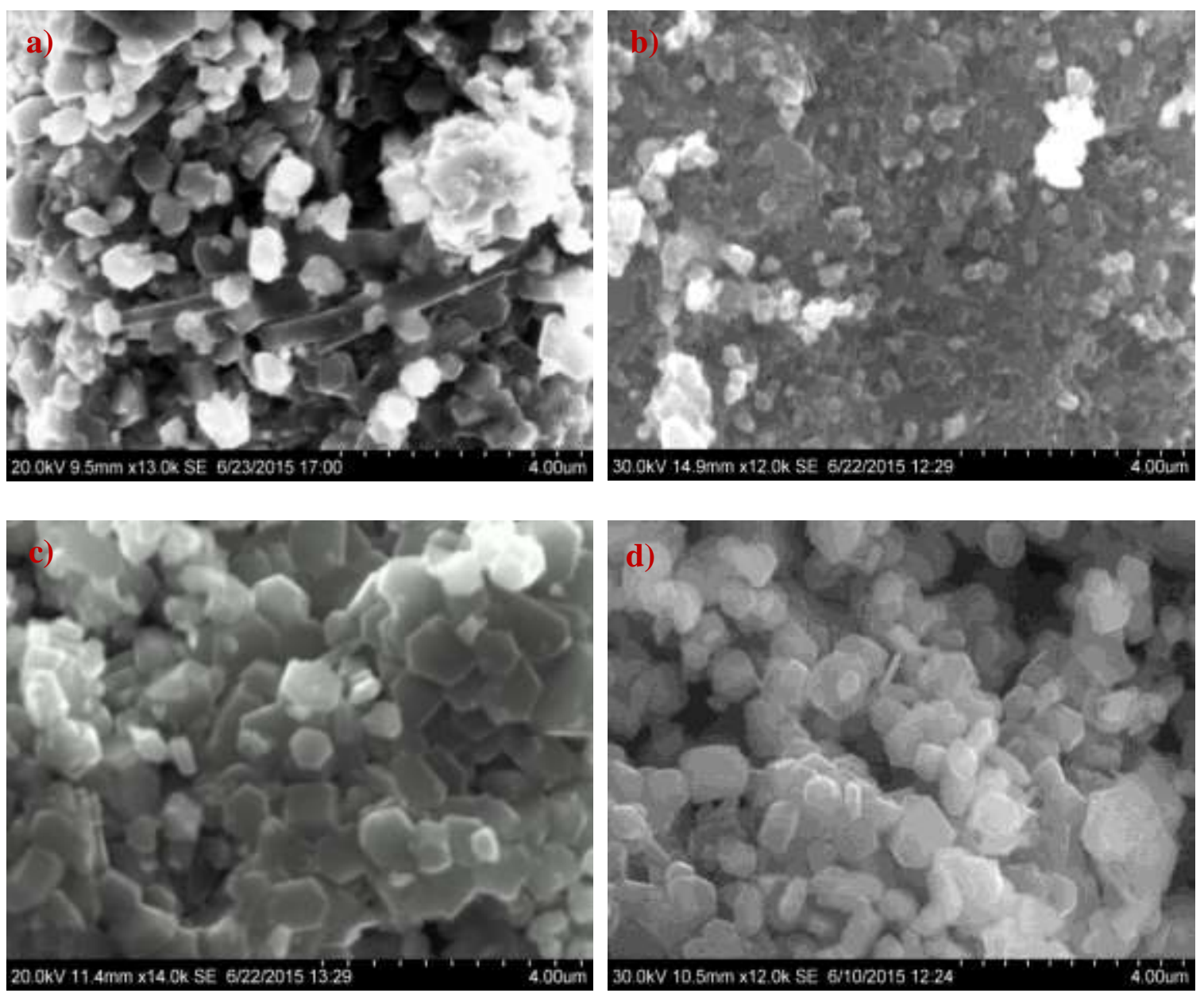
Fig. 4.
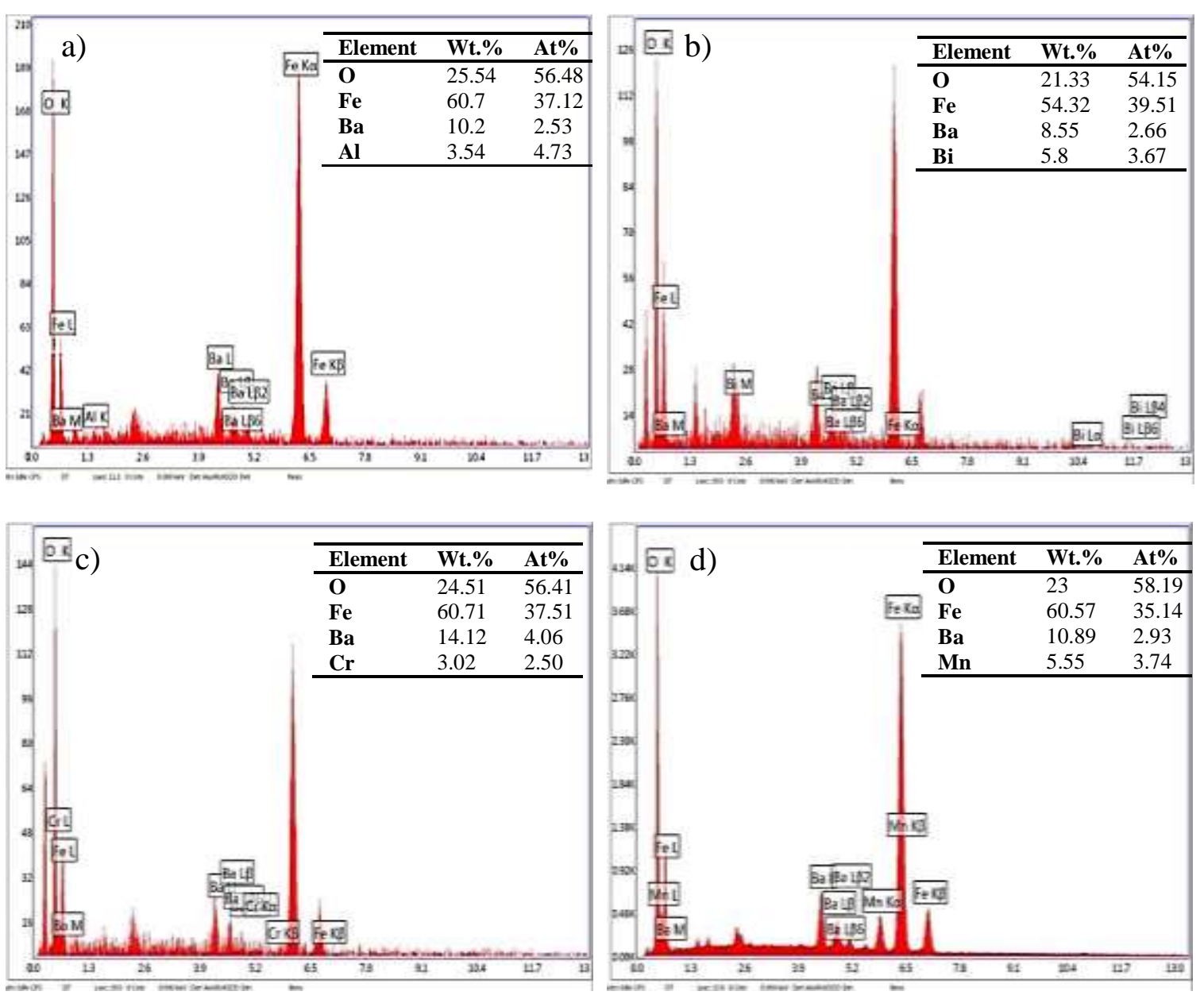
Fig. 5.

\begin{tabular}{|c|c|c|c|}
\hline Site & $r(\dot{A})$ & c & \\
\hline$\pm \mathrm{Ba}$ & 1.42 & 무 & \\
\hline$\boxminus \mathrm{Fe}$ & 0.78 & 뭄 & \\
\hline Fe1 & 0.78 & $\square$ & $2 a$ \\
\hline $\mathrm{Fe} 2$ & 0.78 & ㅁ & 20 \\
\hline $\mathrm{Fe} 3$ & 0.78 & 무 & $4 f_{1}$ \\
\hline $\mathrm{Fe} 4$ & 0.78 & 무 & $4 f_{2}$ \\
\hline $\mathrm{Fe} 5$ & 0.78 & $\square$ & $12 \mathrm{k}$ \\
\hline \pm 0 & 1.00 & $\square$ & \\
\hline
\end{tabular}
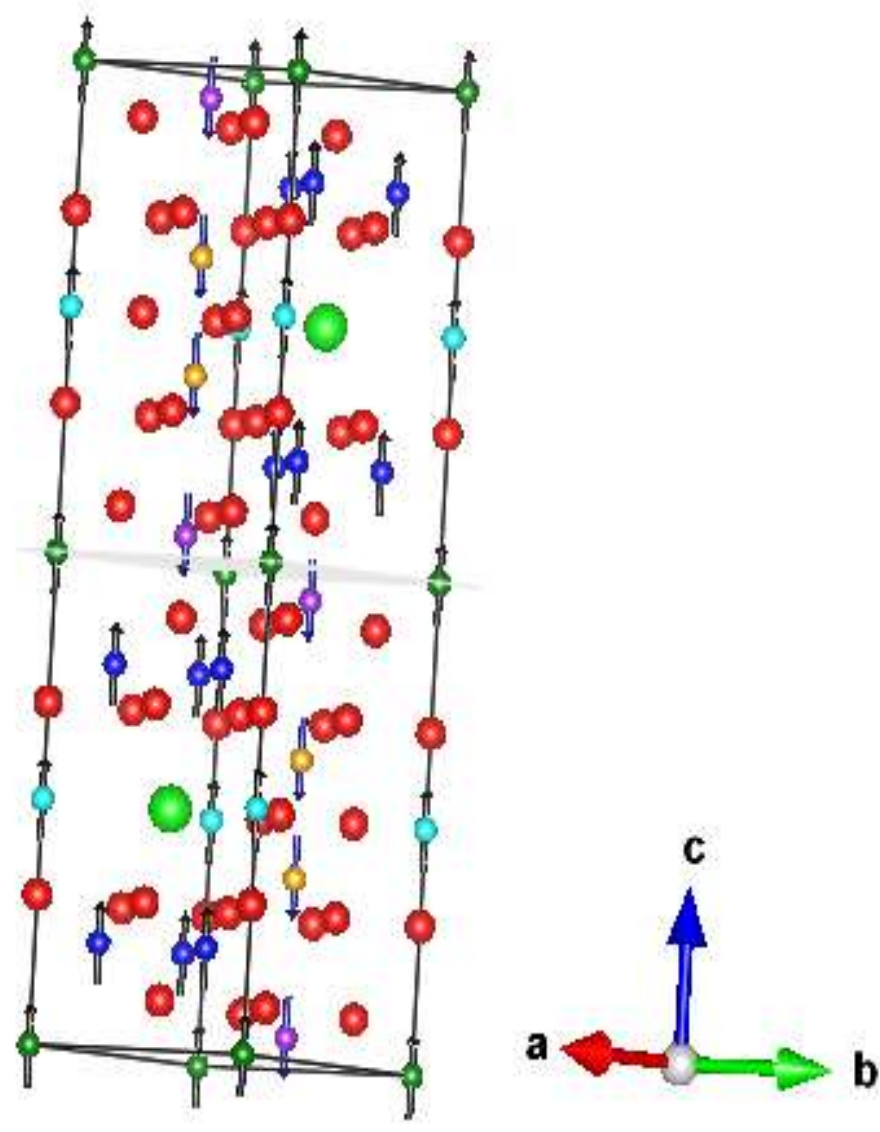
Fig. 6.

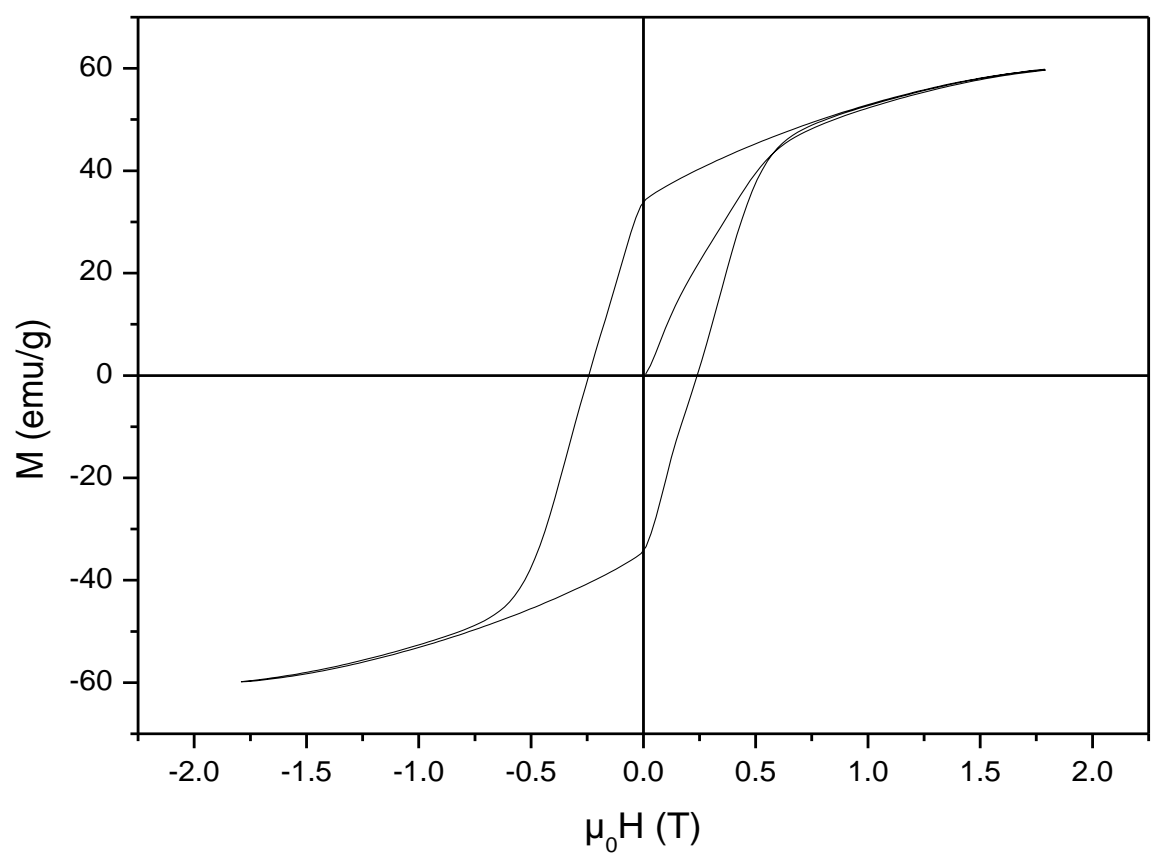


Fig. 7.

a)

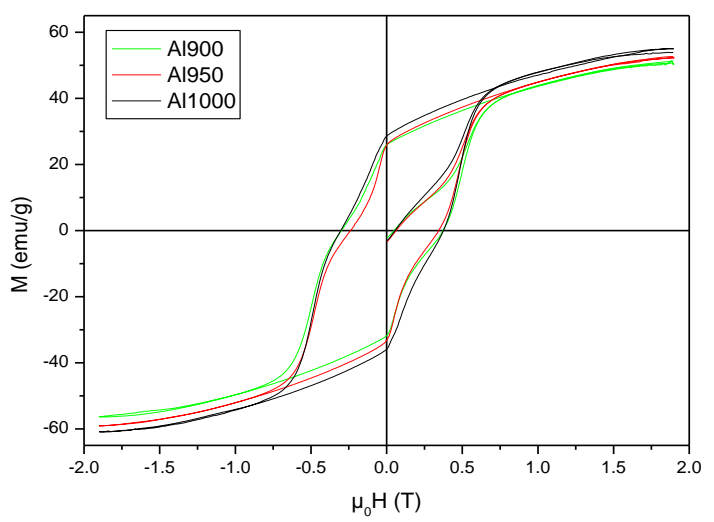

c)

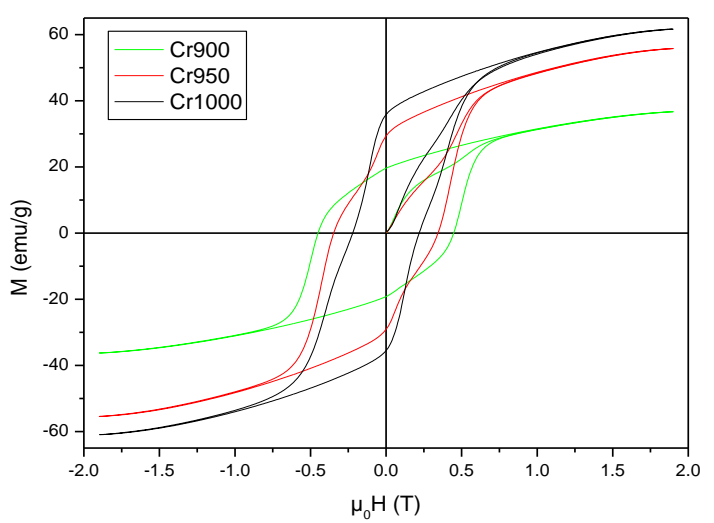

b)

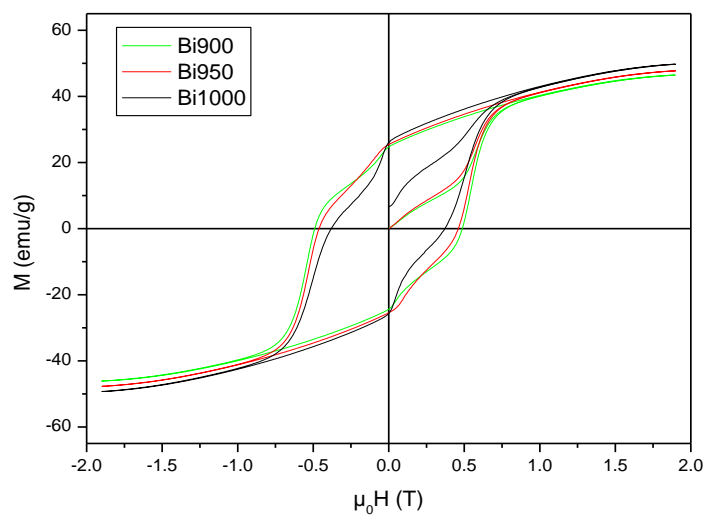

d)

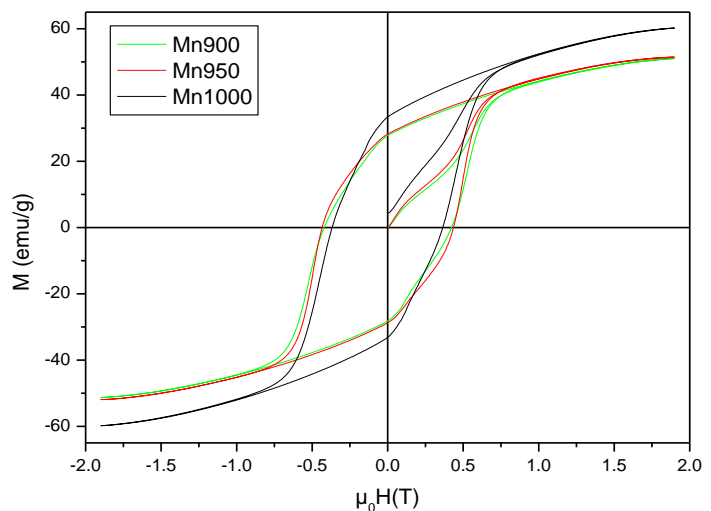


Fig. 8.

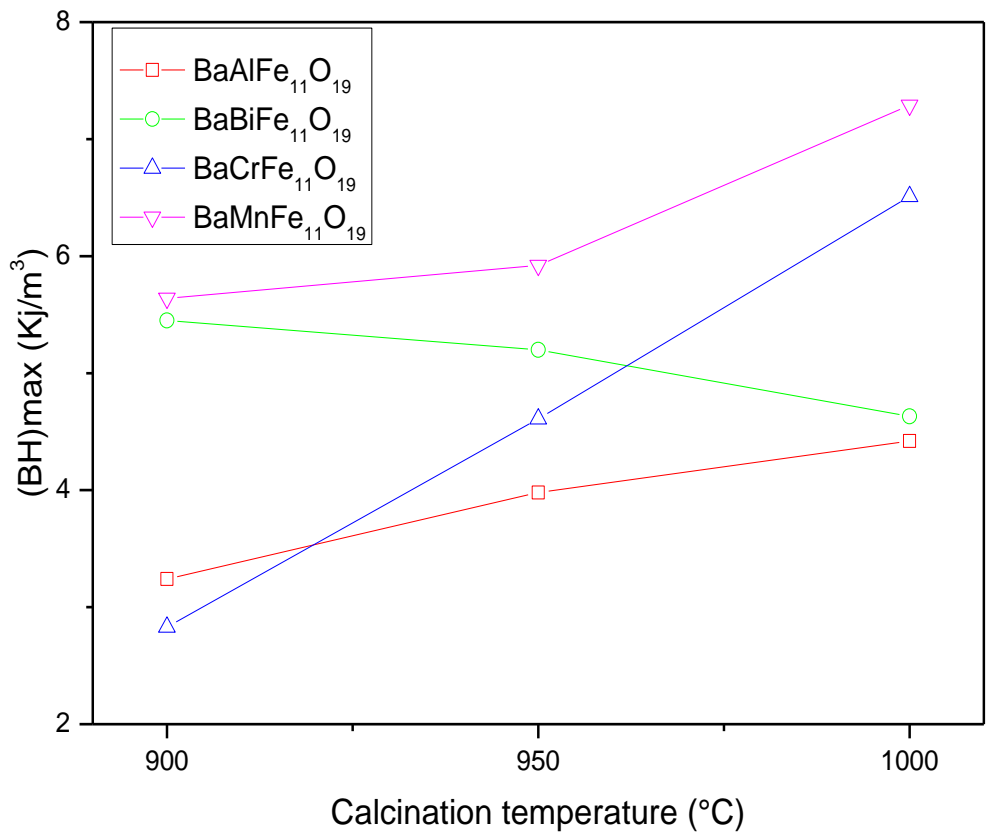


Fig. 9

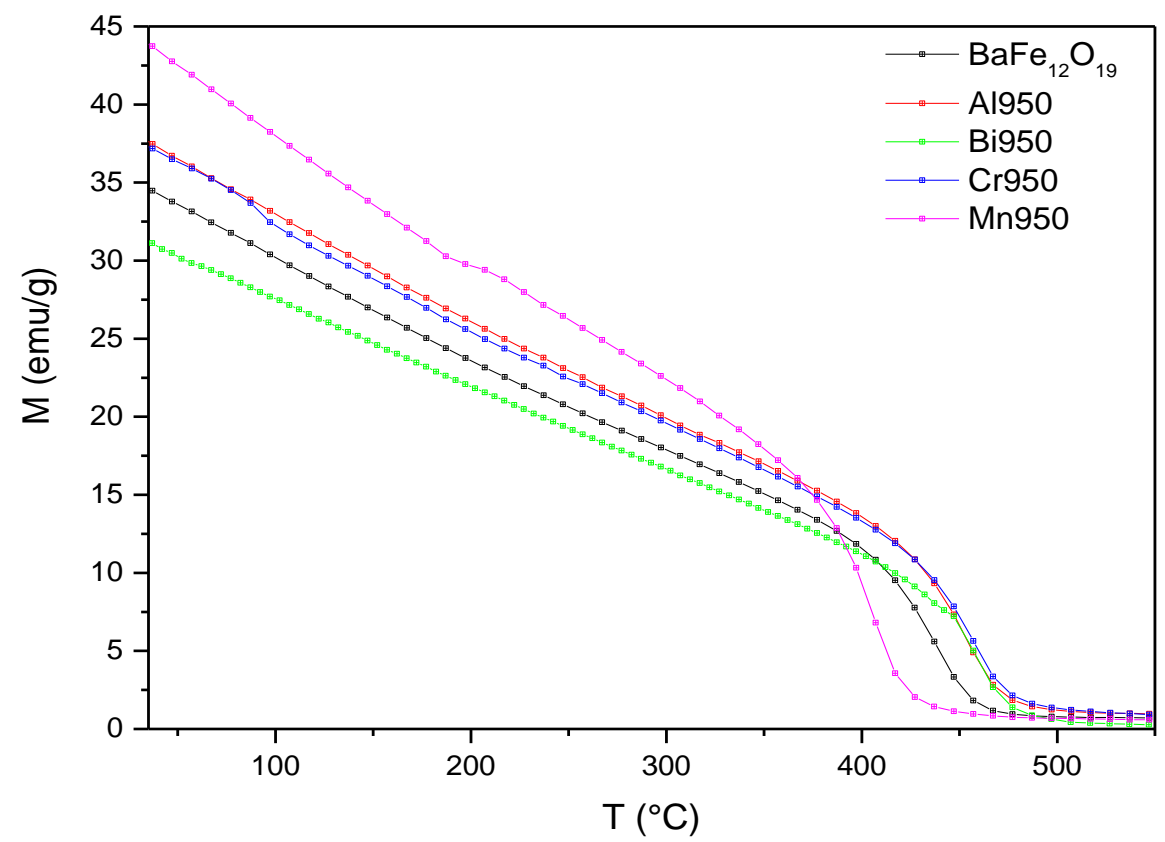

